\title{
Exploring the Innovational Potential of Biomimetics for Novel 3D MEMS
}

\author{
ILLE C. GEBESHUBER ${ }^{1,2,3, a}$, HERBERT STACHELBERGER ${ }^{3, b}$, \\ BAHRAM AZIZOLLAH GANJI ${ }^{1,4, c}$, DEE CHANG FU ${ }^{1, d}$, \\ JUMRIL YUNAS ${ }^{1, e}$ and BURHANUDDIN YEOP MAJLIS ${ }^{1, f}$
}

\author{
${ }^{1}$ Universiti Kebangsaan Malaysia, Institute of Microengineering and Nanoelectronics (IMEN), \\ 43600 UKM, Bangi, Selangor, Malaysia \\ ${ }^{2}$ Institut für Allgemeine Physik, University of Technology Vienna, Wiedner Hauptstrasse 8-10/134, \\ 1040 Vienna, Austria \& $\mathrm{AC}^{2} \mathrm{~T}$ research $\mathrm{GmbH}$, Austrian Center of Competence for Tribology, Viktor \\ Kaplan-Strasse 2, 2700 Wiener Neustadt, Austria \\ ${ }^{3} \mathrm{TU}$ BIONIK, Center of Excellence Bionik / Biomimetics, Institute of Chemical Engineering \& \\ University Service-Center for Transmission Electron Microscopy, University of Technology Vienna, \\ Getreidemarkt 9/166, 1060 Wien, Austria \\ ${ }^{4}$ Department of Electrical Engineering, Babol University of Technology, 484 Babol, Iran \\ aille.gebeshuber@ukm.my, bhstachel@mail.zserv.tuwien.ac.at, cbaganji@vlsi.eng.ukm.my, \\ 'cfdee@vlsi.eng.ukm.my, jumrilyunas@gmail.com, ${ }^{\mathrm{f}}$ burhan@vlsi.eng.ukm.my
}

Keywords: biomimetics, bioinspiration, 3D-MEMS, hinges, interlocking devices, springs, click stop mechanism, multifunctional surfaces, pumps, learning from nature, diatoms, emerging technologies, material, form, structure, complexity.

\begin{abstract}
A novel way to describe the complexity of biological and engineering approaches depending on the number of different base materials is proposed: Either many materials are used (material dominates) or few materials (form dominates) or just one material (structure dominates). The complexity of the approach (in biology as well as in engineering) increases with decreasing number of base materials. Biomimetics, i.e., technology transfer from biology to engineering, is especially promising in MEMS development because of the material constraints in both fields. The Biomimicry Innovation Method is applied here for the first time to identify naturally nanostructured rigid functional materials, and subsequently analyse their prospect in terms of inspiring MEMS development.
\end{abstract}

\section{Introduction}

In biomimetics, materials, processes and systems in nature are analysed, the underlying principles are extracted and subsequently applied to science and technology [1][2][3]. This approach can result in innovative new technological constructions, processes and developments. Biomimetics can aid MEMS developers to manage the specific requirements in systems or product design, which are even more relevant than for conventional products, especially to create products and processes that are sustainable and perform well (e.g. to overcome stiction), to integrate new functions, to reduce production costs, to save energy, to cut material costs, to redefine and eliminate "waste", to heighten existing product categories, to define new product categories and industries, to drive revenue and to build unique brands [4][5].

Recurrent principles in biological materials and systems are hierarchy [6][7] and multi-functionality. Vincent and co-workers analysed 500 biological phenomena, covering over 270 functions, at different levels of hierarchy [8]. Depending on the extent to which each level of the hierarchy is dependent on its lower levels, adaptation or optimization of the biomaterial is independently possible at each level of hierarchy. Size differences between hierarchy levels tend to be about a factor of ten [9]. A major advantage of hierarchical structuring is that the material can be made multifunctional and that a specific material property, such as fracture toughness, can be improved by optimization at different size levels. A direct consequence is the increase in 
adaptability of natural materials. Functions can be modified or enriched by structuring on an additional level of hierarchy. Adaptability increases, therefore, as a function of the number of levels of hierarchy. This is probably why such a wide range of material and structural properties (see Figure 1 for biological $\mathrm{SiO}_{2}$ structures in glass-making microorganisms) can be provided in nature by such a small range of base materials [9][10].

\section{Materials and Methods}

The complexity of biological and engineering approaches depend on the number of different base materials used: Either many materials are used (material dominates) or few materials (form dominates) or just one material (structure dominates). The importance of structures and the complexity of the approach (in biology as well as in engineering) increase inversely with the number of different materials that are or can be used. This can be seen in technology from the macrometer to the nanometer length scale. The Eiffel tower, e.g., which is mainly made from steel, has many levels of structural hierarchy with important structures on every length scale. Also in MEMS and NEMS technology, a limited number of base materials is used (such as $\mathrm{Si}, \mathrm{SiO}_{2}$, Silicon nitride, GaAs, Silicon carbide, diamond, $\mathrm{InP}, \mathrm{SiGe}$, ferroelectric materials and polymers), providing a wide range of functional and structural properties. Because of these material constraints biomimetics is especially promising in MEMS development. The Biomimicry Innovation Method (C) Biomimicry Guild, Helena, MT, USA 2008) is applied to identify high-potential candidates for inspiring emerging MEMS technologies as well as optimising existing ones.

The experience of one of the authors (ICG) on the boundary between biology and engineering, literature search, talks with experts from biology and the AskNature.org database provided by the Biomimicry Institute are utilized in course of the Biomimicry Innovation Method to exploit the large biodiversity in rainforests and in the water bodies of the world and to find biological inspiration for functions such as click-stop mechanisms, micropumps, energy dissipation and lubrication (Table 1). Functions relevant for MEMS are identified, and in the next step, biologised questions such as "How does nature make connections between rigid parts on the micrometer length scale?" or "How does nature pump micro- and nanolitre liquid volumes?" are asked. The basic question is "What would nature do?" with respect to issues that arise in 3D-MEMS development. As third step, Nature's best practices are identified, e.g., by screening the relevant literature or by entering a highly inspiring environment with the biologised questions in mind (task-oriented visit to a habitat with high species diversity, e.g. the rain forest or a coral reef). Thereby a compendium of how plants, animals and ecosystems solve the specific challenge is obtained. The fourth and last step of the Biomimicry Innovation Method is to generate process/product ideas from the best practices ( $90 \%$ of which are usually new to engineers).
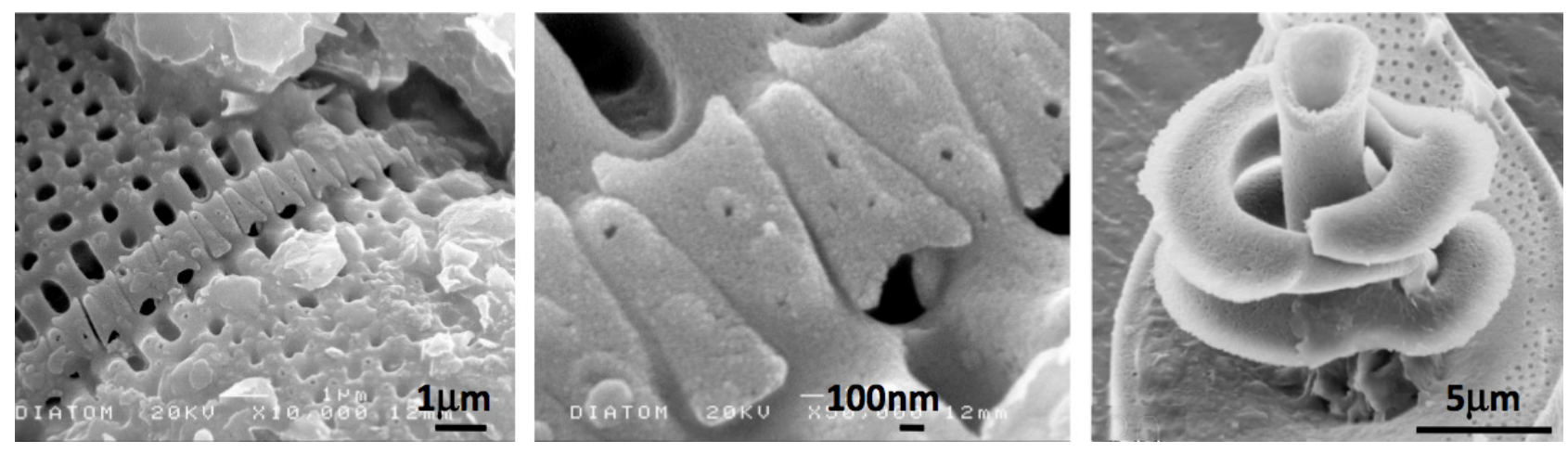

Figure 1: Structure dominated micromechanical components ( $\mathrm{SiO}_{2}$ shells of algae).

Left: Zipper-like structure in Aulacoseira. Middle: Zoom into the same image. (C) Duncan Waddell, XTAL Enterprises, Australia. Right: Spring-like structure in Rutilaria grevilleana. (C) R.M. Crawford, AWI Bremerhaven, Germany. Images used with permission. 


\section{Results and Outlook}

The best practices identified are biological micro- and nanostructures in organisms as diverse as algae, horses, Malaysian tropical rainforest understory plants, peacocks, birds, green algae, humans (immune system), adhesive pads in the gecko and in herbivorous insects as well as the mechanical defence strategies of their food (wax crystals). The summary of the results is given in Table 1 .

MEMS developers interested in including the bioinspired approaches presented in this work have been identified and as next step bioinspired 3D MEMS will be designed and modelled and prototypes will be constructed.

\begin{tabular}{|c|c|c|c|}
\hline \multicolumn{4}{|c|}{ Application of the Biomimicry Innovation Method regarding structure dominated components } \\
\hline Function & $\begin{array}{l}\text { Biologised question: } \\
\text { How does nature ... }\end{array}$ & Nature's best practice & $\begin{array}{l}\text { Generated process/ } \\
\text { product ideas }\end{array}$ \\
\hline $\begin{array}{l}\text { Hinges and } \\
\text { interlocking } \\
\text { devices }\end{array}$ & $\begin{array}{l}\text {... mechanically } \\
\text { connect hard single } \\
\text { cells? }\end{array}$ & $\begin{array}{l}\text { Diatoms in chains (Eunotia } \\
\text { sudetica, Bacillaria paxillifer, } \\
\text { Ellerbeckia sp.) [11][12] }\end{array}$ & $\begin{array}{l}\text { micromechanical } \\
\text { optimization of } \\
\text { 3D-MEMS structure }\end{array}$ \\
\hline $\begin{array}{l}\text { Click-stop } \\
\text { mechanism }\end{array}$ & $\begin{array}{l}\ldots \text { unfold structures } \\
\text { and then irreversibly } \\
\text { fix them? }\end{array}$ & $\begin{array}{l}\text { Corethron pennatum, } \\
\text { Corethron criophilum [12] }\end{array}$ & $\begin{array}{l}\text { obtain 3D structures } \\
\text { from fabricated 2D } \\
\text { structures }\end{array}$ \\
\hline Springs & $\begin{array}{l}\ldots \text { reversibly store } \\
\text { mechanical energy? }\end{array}$ & $\begin{array}{l}\text { Rutilaria grevilleana, } \\
\text { R. philipinnarum [13] }\end{array}$ & $\begin{array}{l}\text { Energy storage in } \\
\text { MEMS }\end{array}$ \\
\hline $\begin{array}{l}\text { Parts connected } \\
\text { in a chain with } \\
\text { adjustable length }\end{array}$ & $\begin{array}{l}\text {... provide stability to } \\
\text { chains in turbulent } \\
\text { environments? }\end{array}$ & Ellerbeckia arenaria [14] & $\begin{array}{l}\text { MEMS with } \\
\text { moveable parts }\end{array}$ \\
\hline $\begin{array}{l}\text { Movable rigid } \\
\text { parts }\end{array}$ & $\begin{array}{l}\text {... optimize moveable } \\
\text { parts? }\end{array}$ & $\begin{array}{l}\text { Melosira sp., Ellerbeckia } \\
\text { arenaria }[14]\end{array}$ & $\begin{array}{l}\text { 3D MEMS with } \\
\text { moveable parts }\end{array}$ \\
\hline Pumps & ... move fluids? & $\begin{array}{l}\text { Rutilaria grevilleana, } \\
\text { Rutilaria philipinnarum [15] }\end{array}$ & $\begin{array}{l}\text { micropumps for } \\
\text { lab-on-a-chip }\end{array}$ \\
\hline $\begin{array}{l}\text { Unfoldable } \\
\text { structures }\end{array}$ & $\begin{array}{l}\text {... generate } 3 \mathrm{D} \\
\text { structures from rigid } \\
\text { parts? }\end{array}$ & $\begin{array}{l}\text { Corethron pennatum, } \\
\text { Corethron criophilum [12] }\end{array}$ & $\begin{array}{l}\text { obtain 3D structures } \\
\text { from fabricated 2D } \\
\text { structures }\end{array}$ \\
\hline $\begin{array}{l}\text { Energy } \\
\text { dissipation }\end{array}$ & $\begin{array}{l}\text {... dissipate } \\
\text { mechanical energy? }\end{array}$ & Solium exsculptum [16][17] & 3D-MEMS \\
\hline $\begin{array}{l}\text { Fracture control, } \\
\text { Crack redirection }\end{array}$ & $\begin{array}{l}\text {... mechanically } \\
\text { protect viable parts? }\end{array}$ & Equus ferus caballus [18][19] & $\begin{array}{l}\text { quality assurance of } \\
\text { MEMS }\end{array}$ \\
\hline Lubrication & ... prevent wear? & Unknown diatom species [20] & preventing stiction \\
\hline $\begin{array}{l}\text { Stability } \\
\text { (reinforcement) }\end{array}$ & $\begin{array}{l}\text {... mechanically } \\
\text { protect viable parts? }\end{array}$ & Solium exsculptum [16][17] & $\begin{array}{l}\text { quality assurance of } \\
\text { MEMS }\end{array}$ \\
\hline Surface texturing & ... structure surfaces? & Solium exsculptum [16][17] & MEMS \\
\hline $\begin{array}{l}\text { Photoprotective } \\
\text { coating }\end{array}$ & $\begin{array}{l}\text {... protect photo- } \\
\text { sensitive plants? }\end{array}$ & $\begin{array}{l}\text { Begonia sp., Diplazium sp., } \\
\text { Phyllagathis rotundifolia [21] }\end{array}$ & MEMS \\
\hline $\begin{array}{l}\text { Photonic } \\
\text { components }\end{array}$ & $\begin{array}{l}\text {... make colours } \\
\text { without pigments? }\end{array}$ & $\begin{array}{l}\text { Peacock, butterfly scales, } \\
\text { iridescent plants, fruits, birds } \\
\text { and mammals [11][21][22][23] }\end{array}$ & $\begin{array}{l}\text { photonic micro- and } \\
\text { nanodevices, } \\
\text { MEMS }\end{array}$ \\
\hline $\begin{array}{l}\text { Pressure resistant } \\
\text { containers }\end{array}$ & $\begin{array}{l}\text {... deal with high } \\
\text { pressures? }\end{array}$ & Euglena gracilis pellicle [24] & lab-on-a-chip \\
\hline Fixation & $\begin{array}{l}\text {... mechanically fix } \\
\text { structures? }\end{array}$ & $\begin{array}{l}\text { Corethron pennatum, } \\
\text { Corethron criophilum [12] }\end{array}$ & $\begin{array}{l}\text { 3D-MEMS, } \\
\text { lab-on-a-chip }\end{array}$ \\
\hline $\begin{array}{l}\text { Selective, } \\
\text { switchable } \\
\text { adhesion }\end{array}$ & $\begin{array}{l}\text {... reversibly adhere } \\
\text { to structures? }\end{array}$ & $\begin{array}{l}\text { Immune system [16][25][26] } \\
{[27][28] \text {, gecko foot }[29][30] \text {, }} \\
\text { insect attachment pads }[31] \text {, } \\
\text { plant wax surfaces [32] }\end{array}$ & $\begin{array}{l}\text { lab-on-a-chip } \\
\text { devices, reusable: } \\
\text { trap, test and release } \\
\text { and start again }\end{array}$ \\
\hline
\end{tabular}




\section{References}

[1] B. Bhushan: Phil. Trans. R. Soc. A Vol. 367 (2009), p. 1445

[2] Y. Bar-Cohen: Biomimetics: Biologically Inspired Technologies, CRC Press (2005)

[3] I.C. Gebeshuber and M. Drack: J. Mech. Eng. Sci. Vol. 222 (2008), 222, p. 1281

[4] I.C. Gebeshuber, A. Pauschitz and F. Franek: in: Proc. 2006 IEEE Conference on Emerging Technologies - Nanoelectronics (2006), p. 396

[5] I.C. Gebeshuber, B.Y. Majlis, L. Neutsch, F. Aumayr and F. Gabor: in: Proc. 3rd Vienna Int. Conf. Micro. Nanotech. - Viennano09, edited by W.J. Bartz and F. Franek, (2009), p. 17

[6] R. Lakes: Nature Vol. 361 (1993), p. 511

[7] P. Fratzl: J. R. Soc. Interface Vol. 4(15) (2007), p. 637

[8] J.F.V. Vincent: J. Theor. Biol. Vol. 236 (2005), p. 73

[9] J. Vincent: Submitted to J. Eng. Med.

[10] G. Jeronimidis and A.G. Atkins: J. Mech. Eng. Sci. Vol. 209 (1995), p. 221

[11] F.E. Round, R.M. Crawford and D.G. Mann: The diatoms: biology and morphology of the genera (Cambridge University Press, Cambridge, UK, 1990)

[12] I.C. Gebeshuber and R.M. Crawford: J. Eng. Tribol. Vol. 220(J8) (2006), p. 787

[13] R.M. Crawford and P.A. Sims: Nova Hedwigia, Beiheft Vol. 133 (2007), p. 171

[14] I.C. Gebeshuber, H. Stachelberger and M. Drack: J. Nanosci. Nanotechnol. Vol. 5 (2005), p. 79

[15] J.Srajer, B.Y. Majlis and I.C. Gebeshuber: Acta Botanica Croatia, in press

[16] I.C. Gebeshuber: Nano Today Vol. 2(5) (2007), p. 30

[17] I.C: Gebeshuber, M. Aumayr, O. Hekele, R. Sommer, C.G. Goesselsberger, C. Gruenberger, P. Gruber, E. Borowan, A. Rosic and F. Aumayr: in: Bio-Inspired Nanomaterials and Nanotechnology (tentative title), edited by Yong Zhou, Nova Science Publishers 2009, in press

[18] M.A. Kasapi and J.M. Gosline: J. Exp. Biol. Vol. 200 (1997), p. 1639

[19] M.A. Kasapi and J.M. Gosline: J. Exp. Biol. Vol. 202 (1999), p. 377

[20] I.C. Gebeshuber, J.H. Kindt, J.B. Thompson, Y. Del Amo, H. Stachelberger, M. Brzezinski, G.D. Stucky, D.E. Morse and P.K. Hansma: J. Microsc. 212(Pt3) (2003), p. 292

[21] K.S. Gould and D.W. Lee: Am. J. Bot. Vol. 83(1) (1996), p. 45

[22] P. Vukusic and J.R. Sambles: Nature Vol. 424 (2003), p. 852

[23] D.W. Lee, G.T. Taylor and A.K. Irvine: Int J. Plant Sci. Vol. 161(2) (2000), p. 297

[24] C. Gruenberger, R. Ritter, F. Aumayr, H. Stachelberger and I.C. Gebeshuber: Mat. Sci. Forum Vol. 555 (2007), p. 411

[25] I.C. Gebeshuber, M. Drack and M. Scherge: Tribology Mat. Surf. Interf., in press

[26] D.F. Tees and D.J. Goetz: News Physiol Sci. Vol. 18 (2003), p. 186

[27] C.E. Orsello, D.A. Lauffenburger and D.A. Hammer: Trends Biotechnol. Vol. 19 (2001), p. 3107

[28] E. Kawasaki and A. Player: Nanomed. Nanotech. Biol. Med. Vol. 1(2) (2005), p. 101

[29] K. Autumn, Y.A. Liang, S.T. Hsieh, W. Zesch, W.P. Chan, T.W. Kenny, R. Fearing and R.J. Full: Nature Vol. 405 (2000), p. 681

[30] US Patent 7056409 - Structures, systems and methods for joining articles and materials and uses therefore

[31] M. Scherge and S. Gorb: Biological Micro- and Nanotribology - Nature's solutions (Springer Verlag Berlin Heidelberg 2001)

[32] E. Gorb, K. Haas, A. Henrich, S. Enders, N. Barbakadze and S. Gorb: J. Exp. Biol. Vol. 208 (2005), p. 4651 